\title{
HERZOGIELLA TURFACEA (LINDB.) Z. IWATS. (PLAGIOTHECIACEAE, BRYOPHYTA) NEW TO TURKEY
}

\author{
HERZOGIELLA TURFACEA (LINDB.) Z. IWATS. (PLAGIOTHECIACEAE, BRYOPHYTA) - \\ НОВЫЙ ВИД ДЛЯ ТУРЦИИ \\ NEVZAT BATAN $^{1} \&$ TURAN ÖZDEMIR ${ }^{2}$ \\ НЕВЗАТ БАТАН ${ }^{1}$, ТУРАН ЁЗДЕМИР ${ }^{2}$
}

Abstract

During our field trips to Ardahan province of Turkey, we have collected some interesting moss samples, such as Herzogiella turfacea (Lindb.) Z.Iwats., which was determined as new for Turkey, Mediterranean basin and Southwest Asia. Descriptions, illustrations, geographic distribution and comparisons with morphologically similar taxa are given.

Резюме

Во время экспедиции в провинцию Ардаган в Турции мы нашли, в числе прочих интересных видов, Herzogiella turfacea (Lindb.) Z.Iwats., которая является новым видом не только для Турции, но и для всего Средиземноморья, равно как и для Юго-Западной Азии. Приводится описание, иллюстрации, отличия от внешне сходных видов и данные о географическом распространении.

KEYWORDS: biodiversity, mosses, Herzogiella, Yalnızçam Mountains, new record, Turkey.

\section{INTRODUCTION}

The geography and climate of Turkey varies remarkably across the country. Turkey has three main floristic regions: Euro-Siberian, Mediterranean and Irano-Turanian (Akman, 1999). So, Turkey is characterized by rich biodiversity of different ecological areas that supply excellent habitats for plants, including bryophytes. The total number of bryophyte species of Turkey have reached 962 (179 liverworts, 779 mosses, 4 hornworts) with the addition of new records (Batan et al., 2014a,b; Abay and Keçeli, 2014, Özdemir and Batan, 2014, Ursava and Çetin, 2014, Ezer et al., 2014, Ören et al., 2015). Compared to other European countries, not many bryophyte flora studies have been conducted in Turkey. On the other hand, Turkey has the highest bryophyte taxa of all countries of Southwest Asia.

This paper reports findings resulting from bryological surveys performed in south east Turkey in the surroundings of Ardahan (Irano-Turanian) (Fig. 1).

According to the checklists of mosses of Turkey, Herzogiella is represented by a species: Herzogiella seligeri (Brid.) Z.Iwats. (Uyar \& Çetin, 2004; Kürschner \& Erdağ, 2005; Kürschner \& Frey, 2011 and Ros et al., 2013).

\section{MATERIAL AND METHODS}

The moss specimens were collected from Eastern Black Sea region (Ardahan province) on 7 September 2014. The samples examined with stereomicroscope (Carl
Zeiss Stemi 2000-C) and a light microscope (Carl Zeiss Axio Imager A2) and their identifications were performed by consulting keys (Ireland, 1992; Noguchi et al., 1994; Frey et al., 2006). The status of taxa was evaluated by reviewing the related literature for Turkey (Uyar \& Çetin, 2004; Kürschner \& Erdağ, 2005; Kürschner \& Frey, 2011; Ros et al., 2013), for Southwest Asia (Kürschner \& Frey, 2011) and for Mediterranean (Ros et al., 2013). Samples are kept in the Herbarium of the Biology Department, Faculty of Science, Karadeniz Technical University, Turkey (KTUB).

\section{SPECIES DESCRIPTION}

Herzogiella turfacea (Lindb.) Z.Iwats.

Fig. 2

Plants pale, green to yellowish-green, glossy, with branches which are $0.8-1 \mathrm{~cm}$ long and simple spreading. Leaves ca. $1.5-1.8 \mathrm{~mm}$, with a long, tapering tip, becoming wavy or irregularly bent when dry, erect-spreading, lanceolate or ovate-lanceolate, narrow acumen, slightly decurrent, usually near the end of the shoots, curve one side. Margin of leaves serrate or dentate near the apex, serrate to serrulate from mid-leaf to basal part. The nerve is indistinct and forked. Mid-leaf cells thin walled, 60-70 $\mu \mathrm{m}$ long, 4-5 $\mu \mathrm{m}$ wide. Alar cells weakly differentiated, not inflated. Setae reddish-brown, ca. 1.5$2 \mathrm{~cm}$ tall. Capsules abundant, reddish-brown or brown, oblong to oblong-cylindrical, curved, ca. 1.5-2 mm long. Capsules furrowed when dry and empty.

\footnotetext{
1 - Karadeniz Technical University, Maçka Vocational School, 61750, Trabzon, Turkey; e-mail: nevzatbatan@gmail.com

2 - Karadeniz Technical University, Faculty of Science, Biology Department, 61080, Trabzon, Turkey; e-mail: ozdemirturan@gmail.com
} 

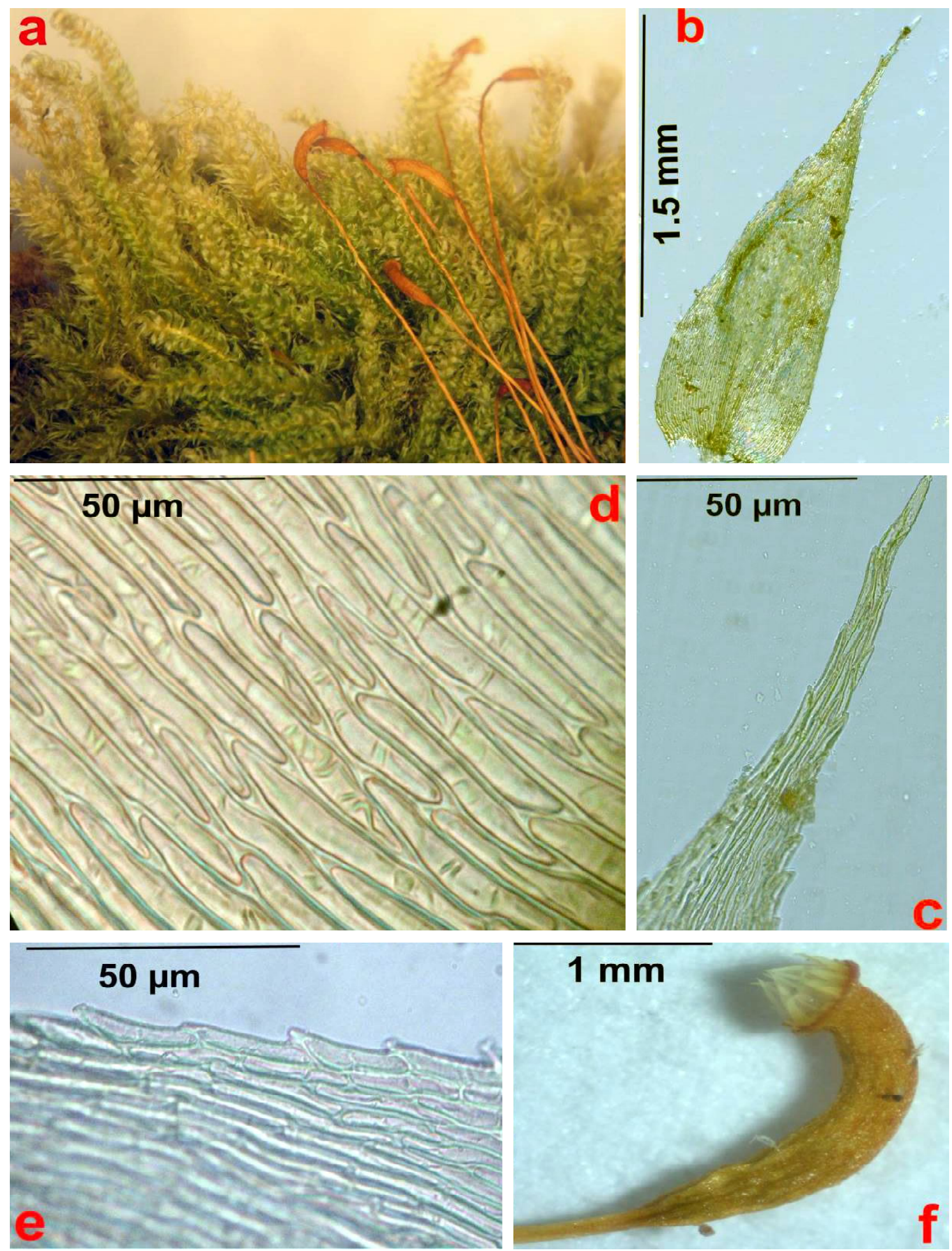

Fig. 2. Herzogiella turfacea (from KTUB 1606): a: habit; b: leaf; c: leaf apex; d: mid-leaf cells; e: leaf margin; f: capsule.

Specimen examined: TURKEY: Ardahan, Hasköy village, Yalnızçam Mountains, Yalnızçam forest, $41^{\circ} 01^{\prime} 44^{\prime \prime N}$, $42^{\circ} 25^{\prime} 15^{\prime \prime} \mathrm{E}$, on rotten log, in the Pinus sp. forest, alt. ca 1893-
1950 m a.s.1., (leg. N. Batan and det. N. Batan \& T. Özdemir), 7 September 2014, KTUB 1606. 
Fig. 1. The collection locality [( $\mathbf{\square})$ Ardahan] of reported taxon and florisic regions of Turkey (borders are shown in dash-lines.

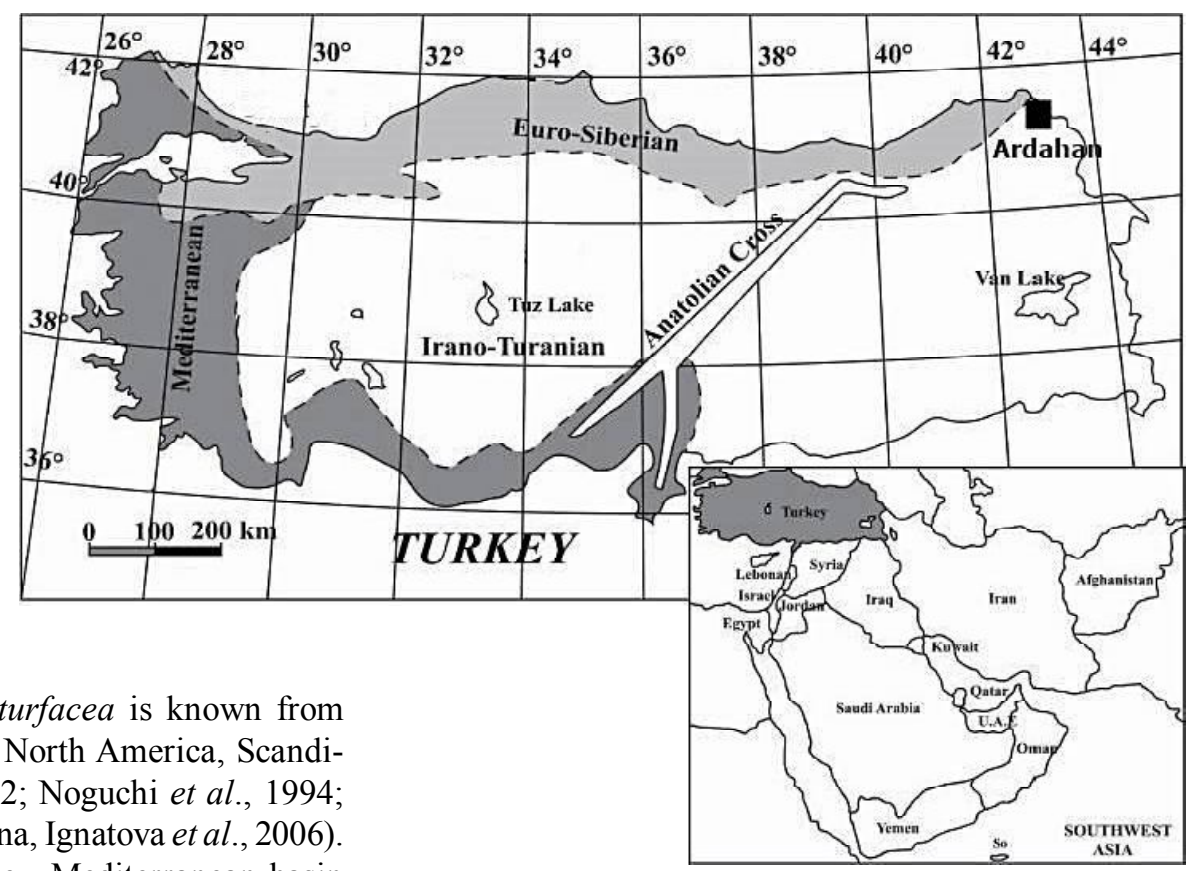

Distribution: Herzogiella turfacea is known from Europe, Japan, Northern Asia, North America, Scandinavia and Russia (Ireland, 1992; Noguchi et al., 1994; Frey et al., 2006; Ignatov, Afonina, Ignatova et al., 2006). It is firstly reported from Turkey, Mediterranean basin and Southwest Asia in this paper.

The genus Herzogiella was represented in Turkey by H. seligeri (Brid.) Z.Iwats. (Uyar \& Çetin, 2004; Kürschner \& Erdağ, 2005; Kürschner \& Frey, 2011; Ros et al., 2013). In this paper, the second species is added to this genus in Turkey, H. turfacea.

Herzogiella turfacea is similar to H. perrobusta (Broth.) $Z$. Iwats., but $H$. perrobusta is distinguished from $H$. turfacea by its mid-leaf cells narrower than those of $H$. turfacea. Additionally $H$. turfacea has leaves and cells of the leaf apex narrower or shorter than those of $H$. perrobusta.

Moreover, $H$. turfacea resembles $H$. seligeri, but $H$. turfacea typically differs from that in having cells of the leaf apex narrower or shorter, and also its capsule is furrowed and 1.5-2 mm long, versus never furrowed, 2-3.5 in $H$. seligeri.

This new record, Herzogiella turfacea contributes to the moss flora of Turkey and Southwest Asia. Moreover, Herzogiella turfacea has been categorized as rare (R) to threats in European moss flora (ECCB, 1995).

\section{ACKNOWLEDGEMENTS}

We are very grateful to the Scientific and Technological Research Council of Turkey TÜBITAK (Project Number: 113Z653) for financial support.

\section{LITERATURE CITED}

ABAY, G. \& T. KEÇELI. 2014. Sphagnum molle (Sphagnaceae, Bryophyta) in Turkey and SW Asia. - Cryptogamie, Bryologie 35: 105-112.

AKMAN, Y. 1999. Climate and bioclimate. Kariyer Matbaacılık, Ankara, $346 p p$.

BATAN, N., Y. JIA, T. ÖZDEMIR \& M. ALATAŞ. 2014a. Brotherella and Encalypta species new to Turkey, Mediterranean and Southwest Asia. - Plant Biosystems 150(3): 436-441; doi: 10.1080/11263504.2014.986247.

BATAN, N., O. ÖZCAN \& T. ÖZDEMIR. 2014b. New Bryophyte Records from Turkey and Southwest Asia. - Telopea 17: 337-346.

European Comittee for Conservation of Bryophytes (ECCB). 1995. Red Data Book of European Bryophytes. - Trondheim, 291 pp.
EZER, T., R. KARA \& T. SEYLI. 2014. Orthotrichum consimile Mitt. new to the moss flora of Turkey. - In: Ellis, L.T. (ed.), New national and regional bryophyte records 41. Journal of Bryology 36 (4): 315.

FREY, W., J.P. FRAHM, E. FISCHER \& W. LOBIN. 2006. The liverworts, mosses and ferns of Europe. English edition revised and edited by T.L. Blockeel. - Harley Books, Colchester, 512 pp.

IGNATOV, M.S., O.M. AFONINA, E.A. IGNATOVA et al. 2006. Checklist of Mosses of East Europe and North Asia. - Arctoa 15: 1-130.

IRELAND, R.R. 1992. Synopsis of the genus Herzogiella for North America. - Lindbergia 7: 111-115.

KÜRSCHNER, H \& A. ERDAĞ. 2005. Bryophytes of Turkey: An annotated reference list of the species with synonyms from the recent literature and an annotated list of Turkish bryological literature. - Turkish Journal of Botany 29: 95-154.

KÜRSCHNER, H \& W. FREY. 2011. Liverworts, mosses and hornworts of Southwest Asia (Marchantiophyta, Bryophyta, Anthocerotophyta). - Nova Hedwigia. 139: 1-240.

NOGUCHI, A., Z. IWATSUKI \& T. YAMAGUCHI. 1994. Illustrated moss flora of Japan, Part 5. - The Hattori Botanical Laboratory, 240 pp. ISBN: 4-938163-09-8-234.

ÖREN, M., B. SARI \& S. URSAVAŞ. 2015. Syntrichia minor (Pottiaceae) and Cephaloziella integerrima (Cephaloziellaceae) new to Bryophyte Flora of Turkey. - Archives of Biological Sciences 67 (2): 367-372.

ÖZDEMIR, T. \& N. BATAN. 2014. New and noteworthy moss records for Turkey and Southwest Asia. - Telopea 17: 35-42.

ROS ESPÍN, R. M., V. MAZIMPAKA, U. ABOU-SALAMA, M. ALEFFI, T. L. BLOCKEEL, M. BRUGUÉS, R. M. CROS, M. G. DIA, G. M. DIRKSE, I. DRAPER, W. EL-SAADAWI, A. ERDAG, A. GANEVA, R. GABRIEL, J. M. GONZÁLEZ-MANCEBO, C. GRANGER, I. HERRNSTADT, V. HUGONNOT, K. KHALIL, H. KÜRSCHNER, A. LOSADA-LIMA, L. LUÍS, S. D. MIFSUD, M. PRIVITERA, M. PUGLISI, M. S. SABOVLJEVIC, C. SÉRGIO, H. M. SHABBARA, M. SIM-SIM, A. SOTIAUX, R. TACCHI, A. VANDERPOORTEN \& O. WERNER. 2013. Mosses of the Mediterranean, an annotated checklist. - Cryptogamie Bryolgie 34(2): 99-283.

URSAVAŞ, S. \& B. ÇETIN.2014. Cinclidotus asumaniae Ursavas \& Çetin (Bryopsida, Pottiaceae), sp. nov., a new species to the hygrophytic moss flora of Southern Turkey. - Nova Hedwigia 98 (3-4): 467-472.

UYAR, G. \& B. ÇETIN. 2004. A new check-list of the mosses of Turkey. - Journal of Bryology 26: 203-220. 